\title{
Evaluation Index System Construction of IPR Process Management on SMEs in China Based on the Life Cycle Theory
}

\author{
Songshan $\mathrm{Li}^{1,}$ a and Xiaofen $\mathrm{Ye}^{2, \mathrm{~b}}$ \\ ${ }^{1}$ School of Management, Wuhan University of Technology, Wuhan 430070, China; \\ ${ }^{2}$ School of Economics and Management, Wuchang Shouyi University, Wuhan 430064, China \\ a2212935613@qq.com, b yexf1983@163.com
}

Keywords: SMEs, IPR Process Management, Evaluation Index, Life Cycle Theory.

\begin{abstract}
The SMEs are important forces in China's technology innovation, and it is the key to enhancing technology innovations of the SMEs' to strengthen the process management of IPR. This paper constructs a set of evaluation index system for the IPR management process performance of SMEs with the 5 primary indexes and 20 secondary indexes from five dimensionalities including the Basic Resources, IPR Creation, IPR Application, IPR Protection, IPR Management based on the Life Cycle Theory, which is helpful to provide theoretical reference to the academia and practice of quantitative research on IPR management performance of the SMEs.
\end{abstract}

\section{Introduction}

SMEs are the important force for technological innovation. It is as high as nearly $70 \%$ of technical innovation and patents are created by SMEs in Germany and the USA. In China, with the full implementation of the innovation driven strategy, technical innovation strength of SMEs is more prominent, and it is necessary for SMEs to realize the value of knowledge innovation results through the process management of IPR. However, it has not formed a scientific evaluation index system of IPR process management for SMEs in existing theory. This paper tries to establish a set of evaluation index system for the IPR process management of SMEs through discussing the its core connotation based on the Life Cycle Theory.

In the 1970s, scholars in Europe and America became the pioneer in the field of IPR management. Hisamitsu Arai (2006) found that the performance of IPR management is related to decision-making in law and technology through the study of Japanese enterprises [1]. James G.Cullem (2010) pointed out that it takes a lot of time and capital to generate enough investment returns [2]. In China, Shouzhong Mo (2012) put forward the strategy construction of IPR management of SMEs in China based on the experiences of Japan and the United States [3]. Qinling Zhou (2014) believed strengthening IPR management is necessary for SMEs to survive in the increasingly fierce knowledge competition [4]. To sum up, it is important and necessary for academia and practice to research IPR process management of SMEs in China considering the research status at home and abroad.

\section{The Connotation of IPR Process Management}

According to the capital axis, IPR process management can be divided into IPR preparation period, IPR formation period, IPR maintenance period and IPR management period by using the Life Cycle Theory. A complete set of processes must be clear, and the corresponding link of capital input and profit output are corresponding. During the research and development period, IPR process management realize various disputes minimization and asset return maximization through various systems and means. Figure 1 shows the patent development process and the corresponding IPR management process based on the Life Cycle Theory. 


\section{Construction of Evaluation Index System for IPR Process Management in SMEs}

\subsection{The Dimensions of Basic Resources}

These are the basis resources of the organization, human, material and finance for enterprise to carry out the IPR strategy, which make up the first-dimension index.

\subsection{The Dimensions of IPR Creation}

The IPR creation is results obtained through the combination of intelligence and technology, and legal protection effect of the IPR only can be obtained through the application and authorization process.

\subsection{The Dimension of IPR Application}

The IPR application reflects the performance of IPR, including the implementation of the patent rate of authorized patent through pilot production after forming the product into the market as well as the situation in the new corporate profits in the contribution of IPR.

\subsection{The Dimension of IPR Protection}

The IPR protection is the process of preventing IPR infringement by various means. The filing rate of IPR disputes, which is the quantitative index of the consciousness and ability of human rights protection, can reflect the litigation ability of enterprises in IPR protection.

\subsection{The Dimension of IPR Management}

Combined with the increasing openness of the market in the technology market, it is of great significance for SEMS to realize the maximization of corporate interests to vitalize existing IPR through flexible mode of operation and enhance the efficiency of resource utilization.

\section{Summary}

This paper builds a set of performance evaluation index system of IPR management process for SMEs from five dimensions consist of the Basic Resource, IPR Creation, IPR Application, IPR Protection, IPR Management based on the Life Cycle Theory (as shown in Table 1). And we will improve the evaluation index system through empirical analysis and application.

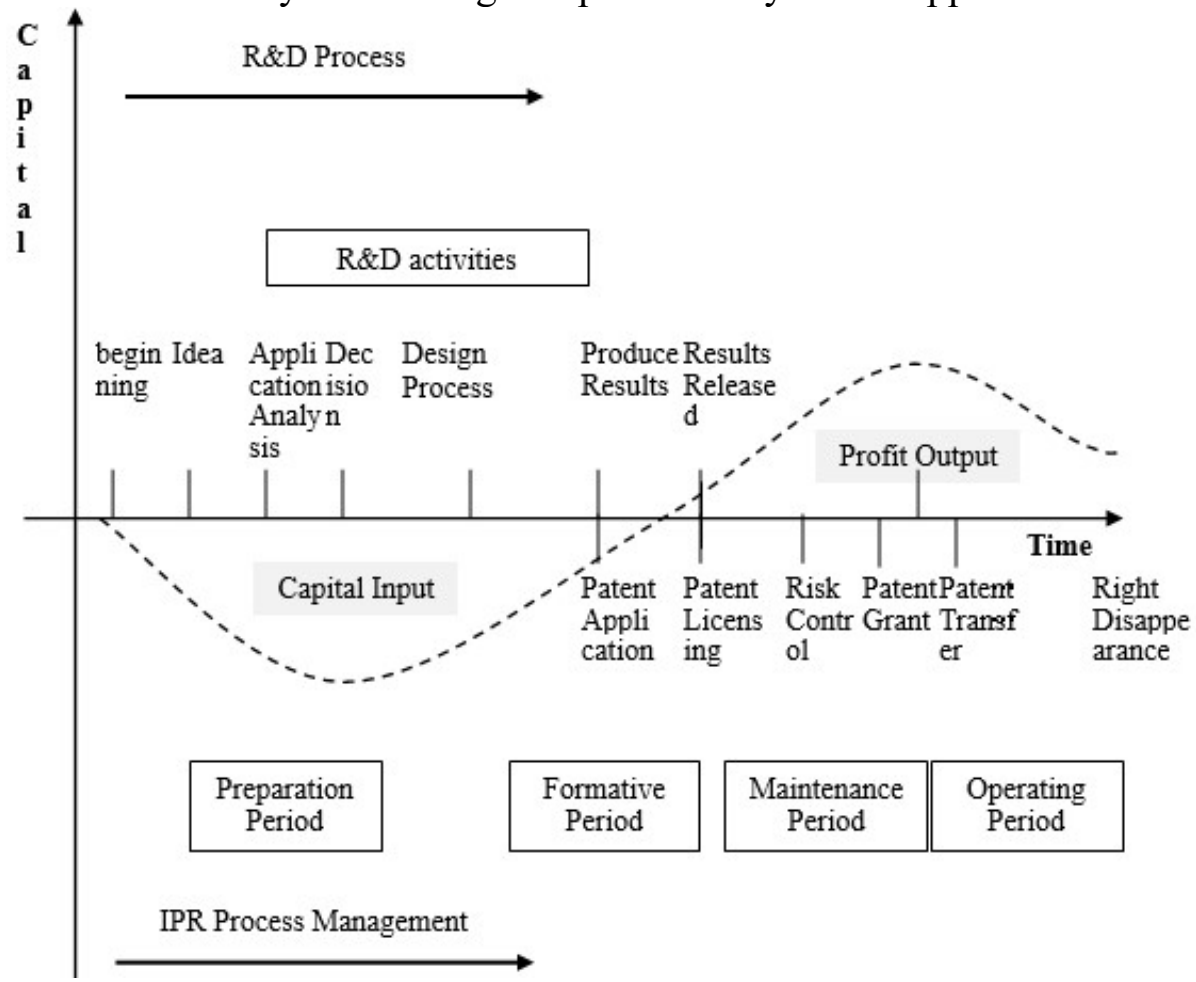

Fig. 1 The framework of IPR process management based on the life cycle. 
Table 1. The SMEs IPR management evaluation index system

\begin{tabular}{|c|c|c|}
\hline $\begin{array}{l}\text { Grade I } \\
\text { indexes }\end{array}$ & Grade II indexes & The calculation formula and explain \\
\hline \multirow{4}{*}{$\begin{array}{l}\text { Basic } \\
\text { Resource }\end{array}$} & $\begin{array}{l}\text { Institutional Settings for IPR } \\
\text { management }\end{array}$ & $\begin{array}{l}\text { The number of full-time personnel, the division of } \\
\text { responsibilities and the rationality of the agency's } \\
\text { functions and powers }\end{array}$ \\
\hline & Special funds for IPR & $\begin{array}{l}\text { Each year the enterprise used for the appropriation of IPR } \\
\text { management. }\end{array}$ \\
\hline & $\begin{array}{l}\text { IPR management information } \\
\text { platform }\end{array}$ & $\begin{array}{l}\text { The construction and application of information platform } \\
\text { analysis }\end{array}$ \\
\hline & $\begin{array}{l}\text { IPR management system and the } \\
\text { work plan }\end{array}$ & Integrity, rationality and execution \\
\hline \multirow{4}{*}{ IPR Creation } & $\begin{array}{c}\text { Research objectives and } \\
\text { strategies }\end{array}$ & $\begin{array}{l}\text { Goals align with corporate strategy } \\
\text { and forward-looking }\end{array}$ \\
\hline & $\begin{array}{l}\text { The investment intensity of } \\
\text { R\&D }\end{array}$ & $\begin{array}{l}\text { Annual enterprise R\&D investment / prime operating } \\
\text { revenue }\end{array}$ \\
\hline & Number of R\&D personnel & Enterprise R\&D personnel quantity \\
\hline & $\begin{array}{l}\text { The number of patent } \\
\text { applications growth rate }\end{array}$ & $\begin{array}{c}\text { The average growth rate of enterprise patents in the last } \\
\text { three years }\end{array}$ \\
\hline \multirow{4}{*}{$\begin{array}{c}\text { IPR } \\
\text { Applicati-on }\end{array}$} & The application rate of patent & $\begin{array}{c}\text { The number of enterprise patent products / The number } \\
\text { of enterprise patents }\end{array}$ \\
\hline & $\begin{array}{c}\text { Contribution rate of IPR for new } \\
\text { profit }\end{array}$ & New contribution of enterprise IPR / new profits \\
\hline & $\begin{array}{c}\text { The use of standardized } \\
\text { procedure }\end{array}$ & Specification of enterprise IPR applications \\
\hline & $\begin{array}{l}\text { The effectiveness of the } \\
\text { competition strategy }\end{array}$ & $\begin{array}{c}\text { The effectiveness of enterprise IPR competition strategy } \\
\text { in market competition }\end{array}$ \\
\hline \multirow{4}{*}{$\begin{array}{c}\text { IPR } \\
\text { Protectio-n }\end{array}$} & $\begin{array}{l}\text { Awareness and ability of rights } \\
\text { protection }\end{array}$ & $\begin{array}{c}\text { Corporate personnel awareness of rights protection and } \\
\text { corporate rights protection }\end{array}$ \\
\hline & $\begin{array}{c}\text { the rate of criminal cases } \\
\text { registered of annual IPR } \\
\text { disputes }\end{array}$ & $\begin{array}{l}\text { The average rate of annual dispute resolution of } \\
\text { enterprises' IPR in the past three years }\end{array}$ \\
\hline & Contract management & $\begin{array}{c}\text { The procedure standardization and backup of enterprise } \\
\text { related contract management }\end{array}$ \\
\hline & $\begin{array}{l}\text { The early warning mechanism of } \\
\text { long-term }\end{array}$ & $\begin{array}{l}\text { The rationality and effectiveness of the early warning } \\
\text { mechanism of enterprise's IPR }\end{array}$ \\
\hline \multirow{4}{*}{$\begin{array}{c}\text { IPR } \\
\text { Management }\end{array}$} & $\begin{array}{l}\text { Annual income and expenditure } \\
\text { plan of IPR }\end{array}$ & $\begin{array}{c}\text { Forward-looking of annual income and expenditure plan } \\
\text { of enterprise IPR }\end{array}$ \\
\hline & $\begin{array}{l}\text { IPR licensing rate and transfer } \\
\text { rate }\end{array}$ & The transaction of IPR in the technology market \\
\hline & $\begin{array}{l}\text { Investment in the introduction of } \\
\text { IPR }\end{array}$ & $\begin{array}{l}\text { The investment quota for the introduction and } \\
\text { transformation of enterprise IPR }\end{array}$ \\
\hline & $\begin{array}{c}\text { Profit contribution rate of } \\
\text { industrialization of IPR }\end{array}$ & $\begin{array}{l}\text { The profit of the IPR of the effective industrialization of } \\
\text { the enterprise / Annual operating profit }\end{array}$ \\
\hline
\end{tabular}

\section{Acknowledgments}

The authors acknowledge the financial support from the key projects from Science and Technology Department of Hubei Province (Grant No.2018ADC020).

\section{References}

[1]. Arai H. The IPR-conscious nation: Mapping the path from developing to developed[M]. WIPO, 2006. 
[2]. Cullem J G. Using IP audits to optimize IP assets[J]. Journal of Commercial Biotechnology, 2010, 16(1): 88-93.

[3]. Shouzhong Mo, Xi Wang, Bei Li. The enlightenment of the developed countries to promote the development of strategic emerging industries with IPR [J]. Journal of hunan university of finance and economics, 2012, 28(2): 5-13.

[4]. Qinling Zhou. Research on strengthening the IPR management of SMEs [J]. Enterprise Reform and Management, 2014 (4): 22-23. 